\title{
Merchants of Helsinki
}

\author{
Jewish stereotypes on a Yiddish stage
}

\author{
Simo Muir
}

DOI: https://doi.org/10.30752/nj.85933

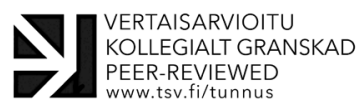

Aвstract - This article analyses a New Year's revue from 1929 by Helsinki-born Jac Weinstein (1883-1976) and the image of the Jewish merchant. Many stereotypes concerning ethnicity and gender are at play in the revue and the line between humour, Jewish self-deprecation and antisemitic depiction of the Jew becomes blurred. The questionable business ethics of Jewish merchants is one of the core themes of the revue. The article asks what role ethnic stereotypes played in Jewish humour before the height of National Socialist racial antisemitism, and what purpose such performances served. It examines the various stereotypes found in the couplets, sketches and one-act plays in Weinstein's kleynkunst performance against the background of transnational Jewish performing arts and current research on Jewish entrepreneurship and antisemitism in Finland.

\section{Introduction ${ }^{1}$}

In 2005, when the Jewish Community of Helsinki was selling a house in the Punavuori district of Helsinki, formerly a centre of Jewish-owned clothing shops and small factories, a cellar packed with forgotten archival material was discovered. Then working at the National Archives of Finland, I was commissioned to create an inventory of the material. The documents included manuscripts of Yiddish plays written by Helsinki-born businessman, playwright and impresario Jac

1 I would like to thank Helen Beer, Laura Ekholm, Riikka Tuori and Hadas Weiss for their assistance and valuable comments about my article. I would also like to thank Yvonne Westerlund for making available her private archives for my research. All mistakes that may remain are mine. I would also like to express my gratitude to the Kone Foundation for funding my research.
Weinstein (1883-1976). ${ }^{2}$ Among these works, which were thought to have been lost, was a New Year's revue from 1929 that satirises in a bold and frank manner the life of local Jewish

2 Jac Weinstein, whose father was a former Jewish soldier of the tsar's army and whose mother was a daughter of a Königsberg rabbi, attended a traditional heder and a Jewish school fashioned after Russian staterun Jewish schools. He went on to study at a local Swedish-language grammar school and was among the first Finnish Jews to enrol in the Imperial Alexander University (now University of Helsinki). At the outburst of the First World War, he fled to Copenhagen in order to avoid conscription to the Russian army. In Copenhagen he married Helsinkiborn Rebecka Seligson (189I-1973), and they soon moved to Stockholm, returning to Helsinki in I92I, when Weinstein obtained Finnish citizenship. There, he became a partner in his brother-in-law's fabric wholesale firm. (Muir 2010) 
merchants. I was surprised to find many stereotypes in the revue and this made me wonder what the purpose of their performance was at the time.

Towards the end of the I920s, the Jewish community of Helsinki suffered an economic and existential crisis. The depression hit the Jewish clothing trade particularly hard, and concentration on the same branch caused tension within the community and pressure from the outside. Antagonism towards Jews was increasing and the Jewish merchants were frequently targeted in the Finnish press. In this atmosphere, the future prospects, especially for the younger generation, seemed gloomy.

One might expect Jewish cultural production in this period to provide hope or self-assertion, and this makes it doubly surprising that a revue like Weinstein's would be staged instead.In the revue many stereotypes concerning ethnicity and gender are at play. The line between humour, Jewish self-deprecation and antisemitic depiction of the Jew is often blurred. The questionable business ethics of Jewish merchants is one of the core themes of the revue. How should we interpret the stereotypes in Weinstein's New Year's revue and how did the spectators understand them? What purpose did the performance of such stereotypes serve, and what role did the ethnic stereotypes play in Jewish humour and society before the height of National Socialist racial antisemitism?

The stereotype of a deceitful Jewish merchant can be traced back to traditional theatre production. This Jewish merchant was also popular in so-called Hebrew comedy in America. According to the theatre scholar Harley Erdman (1997: 19, 65, 80), at the end of the nineteenth century, the depiction of Jewish merchants in American popular entertainment changed from the traditional antisemitic, gloomy and revengeful image of Shylock to a comical and jovial, though still unreliable and cheating, merchant. The image is no longer as one-sided as it used to be. Beneath the mask of the canny merchant could be a caring family man who sympathetically engaged with the plights around him. However, according to Erdman, many of the performances 'clearly bordered on the antisemitic, despite the fact that Jews were active in writing and attending these shows' (ibid. I05). The same applied to German cabaret, and as the historian Peter Jelavich (1993: 6,79) has pointed out, only after the rise of virulent political antisemitism in the I920s did the comicality of such jokes become questionable. Jewish organisations and individuals started to protest, which led eventually to the diminution of the stereotypes (ibid. 20I).

My aim in this article is to analyse how Weinstein depicts the Jewish merchants in Helsinki at the verge of the calamitous I930s for European Jewry, and to discuss the meaning and purpose of these stereotypes. The article starts by contextualising Weinstein's cuvre in the field or Yiddish kleynkunst theatre and by presenting Weinstein's New Year's revue. I will then analyse the image of the Jewish merchant and the stereotypes found in the revue in the light of literature on contemporary transnational Jewish performing arts, and I will also reflect on recent research about Jewish entrepreneurship and antisemitism in Finland in the first half of the twentieth century.

Weinstein's revue offers an alternative approach to the social and cultural history of Finnish Jews and challenges the nationalistic and conventional understanding of ethnicity and integration in pre-Second World War Finland, often seen as unproblematic (see Kuparinen 2008: 276; Muir 20I3). In addition, analysis of Weinstein's sketches provide a new Nordic dimension to the research into Yiddish theatre in general, and to the micro-research field of Yiddish kleynkunst in particular. ${ }^{3}$

3 Yiddish kleynkunst, as well as Yiddish vaudeville, has enjoyed little attention in the past 


\section{Yiddish kleynkunst performances in Helsinki}

The Jewish community in Finland, which had gained civil rights and freedom of profession only with Finnish independence in I9I7, was breaking away from the traditional and religious East European Jewish lifestyle and absorbed with accelerating speed the secular and urban lifestyles and languages of the country's capital, Swedish and Finnish. The linguist Neil Jacobs (2002: 203) has claimed that cabaret among Jews 'became testing grounds for evaluating the achievements, failures and limitations of Jewish emancipation and integration into modern European society'. Similarly, Yiddish theatre in America has been described as a 'secular ritual, a rite of passage from shtetl to assimilation' (Pollak and Greenbaum I998: 127). For Finnish Jews, the shtetlekh, the small towns of the Russian Pale of Settlement with large Jewish communities, were still a fresh memory. There was not a family where one of the parents or grandparents did not come from one of them. Despite the rapid shift from Yiddish to Swedish, in which the younger generation was already fluent, the language of the Jewish cabaret in Helsinki between the world wars was still Yiddish. One could argue that Yiddish was better equipped to dealing with intimate social issues. Swedish - for many born around the turn of the nineteenth and twentieth centuries a second language

among historians of Yiddish theatre, who have focused mostly on the so-called 'legitimate'stage (see Nahson 20I6: 244; Berkowitz 2003: 19). For Yiddish kleynkunst theatre per se, see Nudelman 1968, Sandrow 1996 and Bułat 2oro; for Yiddish vaudeville in New York, see Sandrow 1977, Nahson 2016 and Thissen 20I6; for Yiddish music hall in London, see Lachs 20I8; for Yiddish theatrical performances on amateur stage in the Soviet Union, see Shternshis 2006: 70-I05. learned in school - lacked the vocabulary and expressions and, perhaps more importantly, a tradition to describe the Jewish Diaspora. Things that could be said in Yiddish would have sounded different in Swedish.

Having its roots in Avrom Goldfadn's Yiddish theatre founded in Iași (Yassy), Romania, in I876, modern Yiddish theatre had reached the shores of Finland some thirty years later, when the country was still an autonomous grand duchy of the Russian Empire. ${ }^{4}$ The first known Yiddish theatre group in Helsinki was the dramatic section of the Yidisher literarer $k l u b$, the Yiddish Literary Club, founded by Noach Oberman in 1906, in which Weinstein was also a founding member. In 1922 Weinstein founded the Yidishe dramatishe gezelshaft in Helsingfors, the Jewish Dramatic Society in Helsinki, which functioned until the outbreak of the Second World War (though theatrical performances directed by Weinstein continued during and after the war). The theatre group was fashioned after the model of hundreds of similar societies all over Eastern Europe. Its members were mainly amateurs but there were also some theatre and music professionals. Weinstein's theatre group stood in many ways between the East and the West, absorbing influences, besides Yiddish theatre in Eastern Europe and the United States, especially from German and Swedish cabaret..$^{5}$ Along with

4 On the origin and developement of Yiddish theatre, see e.g. Sandrow I996, Steinlauf 20Io, Berkowitz 2003, Berkowitz and Henry 20I2, Nahson 20I6, Caplan 2018.

5 Whilst it is not known whether Weinstein ever visited Germany, he would have had an opportunity to see visiting German cabaret artists during his time in Sweden and later in Finland. For instance in 1923 Meinhard Maur from the Deutsches Teater in Berlin performed for Jewish audiences in Helsinki (Muir 2004: 60). In general educated Finnish Jews were fluent in German, which they had learned at school and/or independently, read 
classics of Yiddish theatre, such as plays by Jacob Gordin, Sholem-Aleykhem and Sholem Asch, the group performed also Yiddish cabaret, i.e. kleynkunst soirées and longer full-evening revues. (Muir 2004: 48-9, 67-76)

Cabaret had found its way to stages of European Jewish theatres from the first appearances at the Chat Noir in I88I in Paris via clubs in German cities some twenty years later. Typical of cabaret or revue were short skits and songs, both original and parodies of existing ones. The cabaret became a place where society was set under criticism and satire. In the I92os, kleynkunst, as cabaret was often called in Yiddish, was in vogue among East European Jewish sophisticates. The venues brought together people of various skills: artists, musicians, writers, professional and amateur actors. The theatre scholar Nahma Sandrow (1996:323) has described kleynkunst as 'a sort of cabaret revue, witty, gay, and irreverent, rapidly winging from music to dance to monologue to sketch'. According to Sandrow (1977: 94), kleynkunst, which also existed in America, was a little more refined than vaudeville, with its music stemming from art and folksongs, its playlets often by classical writers and in pure Yiddish instead of vaudeville's cheerfully vulgar linguistic hodgepodge. The themes of vaudeville were also quite different from those of European kleynkunst, since the latter revolved around the immigration experience and nostalgia for the Old Home with its traditional religious life style.

Weinstein's Yiddish-language kleynkunst shows were obviously meant to meet the call for Yiddish entertainment in the Jewish community. His revues and soirées also provided a chance to vent difficult social issues. The sociologist Lynn Rapaport (2005: 252) has explained

German literature and were influenced by German culture, which was held in high regard in Finland. that 'humor can serve as social commentary, thus providing a venue for change by lending comedians a forum to discuss social, political, religious, and sexual issues safely. Humor can also help society work through unspeakable difficulties by giving a name and face to evil'. The literary scholar Ruth Wisse (2013: Io) has defined Jewish humour in the following way: 'Jewish joking is the product of an intricate culture, conceived in a Jewish language or idiom, drawing on Jewish memory, and responsive to shared experiences, especially of the deleterious kind'. This often self-deprecating nature of Jewish humour, found also in Weinstein's plays, makes performing it challenging. A joke may work differently depending on the performers and listeners and on the general social climate of the time. According to Wisse (ibid. 34), Sigmund Freud made 'a distinction between jokes directed by Jews at Jews and jokes directed at Jews by foreigners - not because the former are any kinder, but instead because Jews know the connection between their own faults and virtues'.

\section{Weinstein's New Year's revue}

Weinstein's New Year's revue appears on the cover of the printed programme under the Swedish name 'Revyafton', Revue evening (Program 1929) (see Fig. I). Yiddish performances in Helsinki were often advertised in Swedish, the official language of the community at the time. Inside the leaflet, all the programme details are in Latinised Yiddish. The revue was performed on New Year's Eve, 3I December 1929, in the festive hall of the Jewish Co-educational School by the Jewish Dramatic Society in Helsinki. The manuscript of the revue, which is the only remaining nearly complete revue by Weinstein, consists of to8 typed folios in Latinised Yiddish (instead of using Hebrew characters, as would usually have been the case). It includes several working versions of the couplets and sketches as 


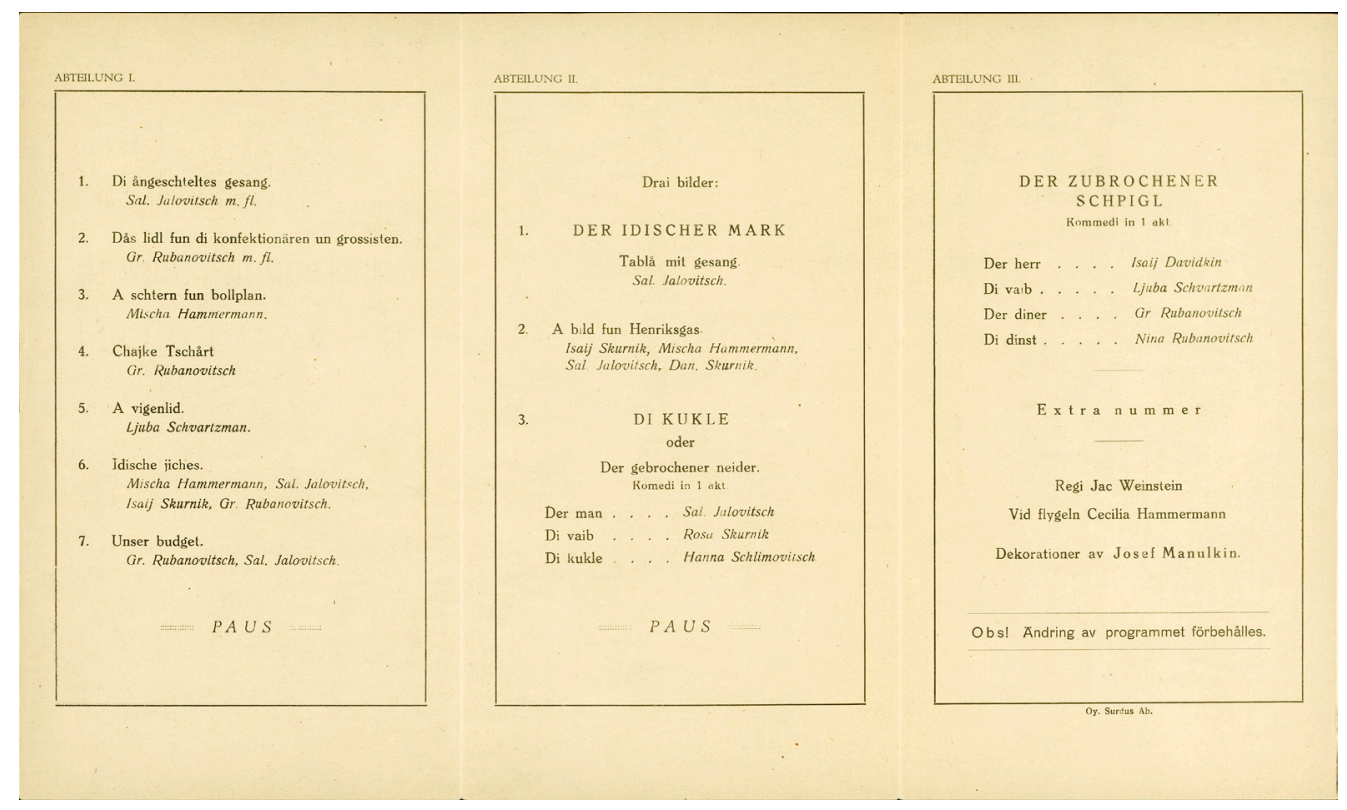

Fig. 1. The printed programme for the New Year's revue in Latinised Yiddish and Swedish shows the how the evening was divided into three sections, very much in the style of revues in the Weimar Republic. Finnish Jewish Archives, National Archives of Finland.

well as items that did not end up in the final programme (Weinstein 1929). ${ }^{6}$ It appears that Weinstein, the author and director of the piece, performed the role of the conférencier, the master of ceremonies. His lines are absent from the manuscript, except for one rhymed fragment probably meant to end the show, in which he begs forgiveness for his outspokenness and suggests reconciliation:

Ikh efsher hob gezindikt haynt

Un a bisl shtreng geven.

Dokh veln mir farblaybn fraynt

$V i$ mir es zay'n geven biz haynt

$V i$ gornit volt geshen.

Un gornit iz geven. ${ }^{7}$

6 A part of the revue, the one-act play called Der tsebrokhener shpigl, can be found in Yvonne Westerlund's private archive. The play is written in Hebrew letters and was probably one of the first drafts of the manuscript.

7 The Yiddish transliteration used in this article follows the YIVO standard. In the references
I may have sinned today

And been a bit harsh.

Despite all that, we will remain friends

As we have been until today

Like nothing ever happened.

And nothing ever was.

Weinstein's revue follows the tradition of annually updated New Year's revues, which had been popular in Paris and were becoming popular in Berlin in the beginning of the twentieth century (Jelavich 1993: I06). Besides the effects of economic depression, Weinstein's cabaret deals with other societal issues that can be found in the minutes and archival material of the Jewish community. These include attempts to maintain a traditional orthodox Jewish lifestyle

the titles are in the original Latinised form, which reflect the peculiarities of Helsinki Yiddish. Weinstein's Latinisation, often not consistent, is based on Swedish orthography, where for instance å stand for Yiddish $O$ (ฟָ). See Muir (2004: I35-I36). 


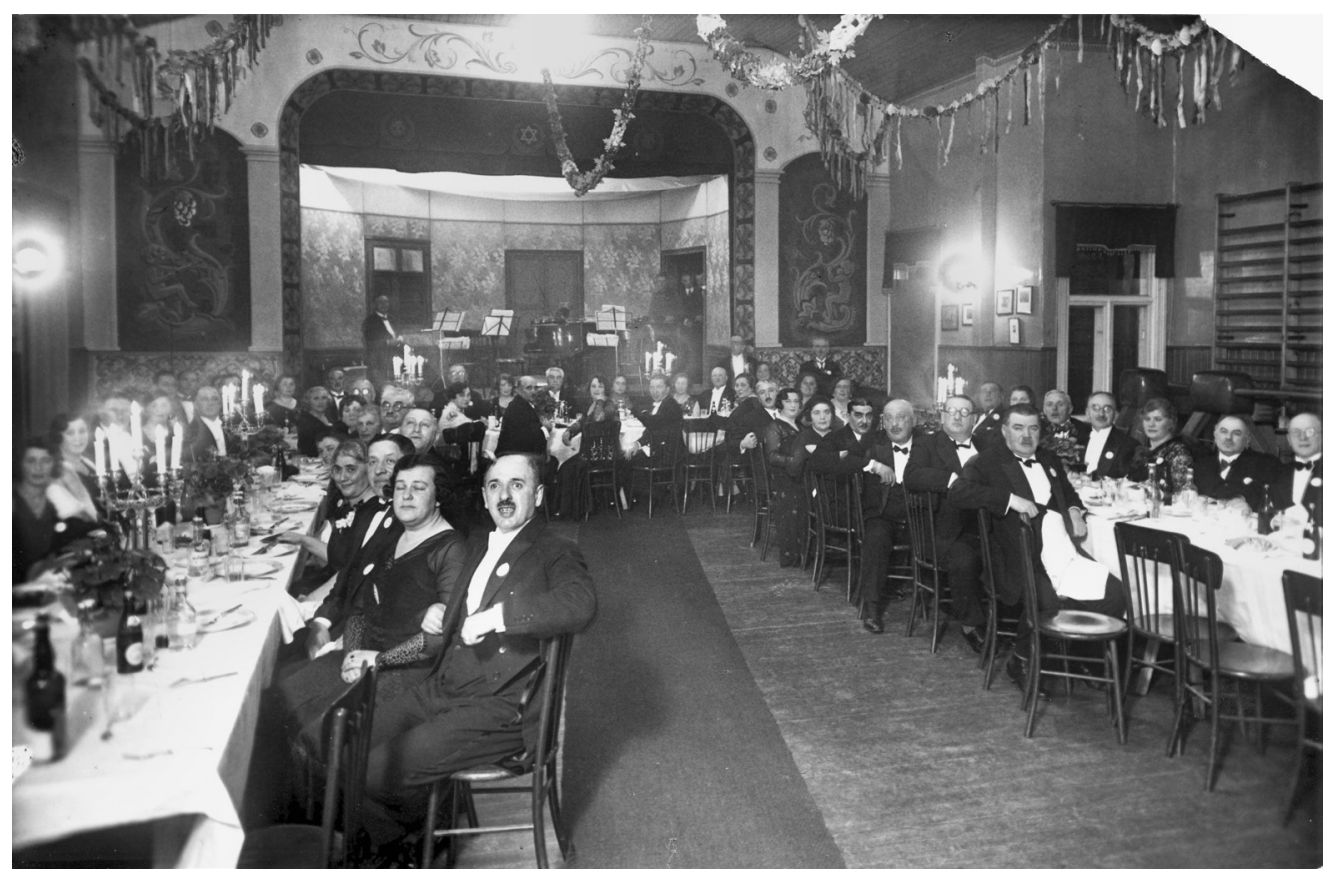

Fig. 2. There are no known pictures of Weinstein's New Year's revue. However, a picture taken during the birthday party of clothing manufacturer and businessman Moses Skurnik on 17 December 1930, in the festive hall of the Jewish Co-educational School, shows a stage design that corresponds with descriptions found in Weinstein's manuscript of the revue. Courtesy of Dorrit Skurnik, Helsinki.

against increasing secularisation, and discussions about the future prospects of the young in a society growing hostile towards Jews. It is noteworthy that Weinstein's revue is devoid of political matters, including Jewish politics, or issues relevant to the wider Finnish society. According to Jelavich (ibid. 5, 154), during the I920s, revues in the Weimar Republic tended to avoid political statements; sexuality and gender were much more prominent themes, as was also the case in Weinstein's New Year's revue. However, politics became more visible in the Weimar revue towards the end of I920s, and especially after the Great Depression and the increasing success of the Nazis (ibid. I39, I87). There is some evidence that Weinstein's revues made a similar turn in the wake of the growing power of the extreme right in Finland, especially when Finland was co-belligerent with Nazi Germany during the Second World War. In a sketch of a Purim-shpil from I944,
Weinstein ridicules the Nazi German racial paradigm by drawing attention to the Reich's minister of propaganda Joseph Goebbels' 'Jewish nose' (Muir, forthcoming). ${ }^{8}$

The structure of the New Year's revue follows that of programmes at the Buntes Theater in Berlin (the first German cabaret founded in I90I), where the first third of the evening was devoted to songs and the second and third parts of the show included longer works (Jelavich 1993: 44). Weinstein's revue starts similarly, with seven couplets that satirise the Jewish clothing trade and Jewish social life. ${ }^{9}$

8 Some of Weinstein's war-time poetry in Swedish, e.g. Judestjärnan - Davidssköld (Jewish star - David's shield; 23 October 1943) and one sketch written in Swedish, Rapporten (Report; I7 November I943), deal with the percecution and annihilation of Jews in German-occupied countries (Muir, forthcoming).

9 The couplets in the order of the programme 
A pause is followed by two sketches, or tableaux as they are referred to in the programme, and a short one-act comedy about the Jewish clothing trade. ${ }^{10} \mathrm{~A}$ second pause is followed by a longer one-act comedy called the Der tsebrokhener shpigl (The broken mirror), set in the house of a nouveau riche clothing merchant. ${ }^{11}$ Weinstein's stage design also seems to have been influenced by the style of the Buntes Theater, where cabaret shows were performed in a private salon milieu (Jelavich I993: 46). One of the rare pictures of the stage in the festive hall of the Jewish Co-educational School from December 1930 shows a bourgeois salon decoration that matches the stage description of Der tsebrokbener shpigl (see Fig. 2). ${ }^{12}$ After the revue programme, a 'special number' was performed, and was most likely followed by music and dance - a New Year's ball.

\section{The image of Jewish merchants in Helsinki}

Weinstein's New Year's revue depicts the Jewish community as vital and modern, in line with cabaret's general tendency to reflect and

(in original Latinised Yiddish): Di ångescbteltes gesang (The employees' song), Dås lidl fun di konfektionären un grossisten (The song of clothing retailers and wholesalers), A schtern fun bollplan (A star from the football field), Chajke Tschart (Khayke the Devil), A vigenlid (A lullaby), Idishe jiches (Jewish lineage), and Unser budget (Our budget) (Weinstein I929).

10 The sketches are: Der idisher mark (The Jewish market) and $A$ bild fun Henriksgas (A scene from Henrik's Street); and the one-act comedy: Dikukle - oder Der gebrochener neider (The mannequin doll - or The broken oath). (Weinstein 1929)

11 Title in Weinstein's original Latinisation Der zubrochener schpigl (Weinstein 1929).

12 According to the programme (Program 1929), the stage for the New Year's revue was designed by Josef Manulkin (later Manuel, I908-2009), a student at the Academy of Fine Arts in Helsinki. define the conditions of life in a metropolis, i.e. the latest fashion, consumerism, the hectic nightlife with its music and so forth (Jelavich I993: 85, IO9, II3). According to the economic and social historian Laura Ekholm (2019: 86), 'the rise of the modern garment industry with standard-sized ready-to-wear clothing is inevitably one of the markers of a modern, industrialised consumer society'. Jewish merchants in Helsinki were concentrated in the clothing industry and were pioneers in the retail of low-cost ready-to-wear clothing (Ekholm 2019; 2013; 2005). The Jewish clothing shops (referred to in Swedish at the time as konfektion, from French confection, i.e. ready-to-wear garment), alongside hat and fur ateliers, were dominant in the urban landscape of Helsinki. Henrik Street (today Mannerheim Street), Helsinki's main road, had several Jewishowned shops, and as many as fifteen adjacent Jewish businesses in 1929 (Ekholm 2005: 18I). Jews' prominence in the ready-to-wear clothing industry is reflected in the first couplet of the revue, Di ongeshteltes gezang (The employees' song), which is an energetic song of the younger generation, clothing-shop assistants. The couplet is sung by a group of men to the melody of the Hebrew song Im eyn ani li mi li, which adds an ironic twist to the song because its original words are 'If I am not for myself, who is?' Di ongeshteltes gezang contains a battery of real names of Helsinki Jewish shops, many of which carried the family name of the owner. The names show also how many of the businesses strove to distinguish themselves as French or English:

\section{In konfektsyon mir dinen. Es ligt in undzer blut.}

Un undzere balebatim ir kent zey ale gut: Au Bon Marché un Prima, Confection de Paris

Un Confection des Modes, Confection Company. 


\author{
Refreng: \\ Un Jakobovitsch un Rakevitsch, Old England \\ un J. Schik \\ Un Savlansky un Waprinsky, Cho Stiller, \\ Kubelik.
}

In a clothing shop we work. It runs in our blood.

And our employers, you know all of them well:

Au Bon Marché and Prima, Confection de Paris

And Confection des Modes, Confection Company.

\section{Refrain:}

And Jakobovitsch and Rakevitsch, Old England and J. Schik

And Savlansky and Waprinsky, Cho Stiller, Kubelik.

Name raps like this were characteristic of assimilated Jewish revue in German-speaking countries (Jacobs 2002: 204). The line 'It runs in our blood' suggests that being part of the clothing business was practically inevitable. The entire Jewish community was connected to the clothing trade in one way or another, and many of its young cut their education short to go straight into the clothing business, mostly retail (Ekholm 2005: I80). Even high-school and university graduates like Weinstein himself joined the clothing trade in the wake of the rg2os economic boom. The couplet called A vignlid (A lullaby), the melody of which is unknown, satirises this one-sided occupational structure and limited prospects for Jewish youth. The irony in the scene lies in the disparity between the image of a mother and child and the contents of the song. The mother foretells the future of her son:

Vi der tate vestu lebn

In a fintstern krom,
Nemen vos der vint vet gebn,

Geyen mitn shtrom

Like your father you will live

In a murky shop,

You'll take what the wind will bring you,

And you'll go with the flow.

The fact that the young were following in the footsteps of their parents was seen as a problem in the community and special grants were given to encourage adolescents to study and gain university degrees (Ekholm 2005: 186).

The economic depression in Finland that started over a year earlier hit the clothing industry especially hard. Many companies, among them the wholesale firm J. Linder Ltd, where Weinstein himself was a shareholder, had gone bankrupt in 1928 (Muir 20IO). Weinstein's satire was thus also self-irony. Anxiety over the clothing industry is the theme of the couplet called Dos lidl fun di konfektsyonern un grosistn (The song of the clothing retailers and wholesalers), sung by a group of men to the cheerful foxtrot melody of Constantinople by Harry Carlton from 1928. Retail was painfully slow, adding pressure on the wholesalers who had more at stake:

Fun Henriksgas un Hagneskayen

Loyfn mir arum un mir shrayen:

Es iz nit gut!

Un fun Robertsgas zey loyfn,

Kukn oyb mir do epes farkoyfn.

Men lakbt mit blut...

Un der zeyger shlogt do bald dokh tsvey

Un der veksl vart dokh nit. Oy, vey!

Refreng:

Konfektsyonern un grosistn mir zaynen dokb ale di faynste fun shtot.

From Henrik's Street to Hagnäs Strand

We run about and we shout: 
It is not good!

And from Robert's Street they run

And look if we sell something here

People laugh with the taste of blood in their mouths

And the clock soon strikes two

And the I.O.U. does not wait. Oh no!

\section{Refrain:}

Clothing retailers and wholesalers we all are indeed the best in town.

The couplet goes on to tell how the merchants earn hardly anything at all and that one merchant's misfortune, even if a competitor, affects the entire Jewish trade: 'Ven fun undz makht eyner pleyte / Vern ale mir poshet bald teyte ...' ('When one of us goes bankrupt / We'll all end up dead soon ...'). According to Ekholm (2006: II8), the depression in Finland between 1928 and 1932 exposed the economic vulnerability of the community in its one-sided occupational structure. One bankruptcy could set off a domino effect, making many other Jewish businesses collapse.

As a contrast and flip-side of fancy shops selling the latest continental fashion, the revue presents the viewers with a Jewish market in Helsinki that trades in trapkes, 'rags'. According to Jelavich (1993: ro9), depictions of the past can be a means to accentuate the modernity of the present. The Jewish market, or Narinkka, from the Russian phrase na rynke (at the market), where still some forty less-fortunate families were selling secondhand clothes, was just around the corner from the elegant Henrik Street (Ekholm 2005). The market had been there for sixty years and it was a popular shopping place for members of the working class. Most Jewish families started their business at this market as a result of earlier restrictions in livelihood. The so-called 'Narinkka Jews' had been a laughingstock for Finnish variety theatre at the turn of the century (Seppälä 2009: I69, 285). By the late I92os, with the social and economical rise of local Jews, the market had become for them a shameful reminder of the past and of the humiliating Jewish statutes they had to endure. In a song from the sketch Der yidisher mark (The Jewish market) the place is described as follows (sung to the melody of $A$ yidishe troyke arranged by Joseph Rumshinsky):

\section{Men hert bay undz imer say fri i say shpet} A nomen, vos klingt nit gehoybn.

Men makht mit dem kop ven men fun es redt, Vayl keyner vil dem nomen nit loybn, Fun fintstern geto es hot a gerukh Un fun ire ayzerne tsamen, Fun shpot un farfolgung, fun laydn un fukhDer yidisher mark iz der nomen.

\section{One hears among us constantly,} early and late,

A name that does not sound exalted.

One shakes one's head when talking about it,

No one wants to praise it.

It reeks of the gloomy ghetto

And of its iron fences,

Of mockery and persecution, of suffering and curse -

The Jewish market is its name.

There was an even stronger reason for introducing the topic in the New Year's revue: in I929 the Helsinki city authorities were planning to close the market down. This led to petitions and bitter protests from among the Jewish salespeople. By I930, the Jewish market had nevertheless closed down (Ekholm 2005: Io6). The timing could not have been worse, as some merchants who had gone bankrupt during the depression were forced to return to the Jewish market, to the 'poor mother' as the song puts it. 


\section{Stereotypes of dubious business ethics}

Despite the depression, the revue depicts the economic rise of many Jews during the boom of the I920s and mocks the excesses of the nouveau riche. Along with the civil rights, when Finland became independent in I9I7, Jews gained the freedom to choose their occupation (Ekholm 2013: 17, 32). Consequently, many families established their own clothing shops and flourished during the economic boom of the i92os. In the one-act comedy Der tsebrokhener shpigl, the viewers get a glimpse of the life of nouveau riche $\mathrm{Mr}$ and Mrs Grossist (lit. wholesaler) who party at the most exclusive restaurants, go to the theatre, dress according to the latest fashion and travel abroad to spas. Much of the comedy lies in a pantomime, where the butler and maid, his fiancée, act as their master's and mistress's reflections in a dressing mirror broken by accident when the master and mistress were out. The master was at a board meeting trying to resolve problems with keeping up a traditional Orthodox Jewish lifestyle, and the mistress was at a meeting of the women's charitable trust fund-raising for the Jewish unemployed. Both come home separately and so drunk that they cannot see that the mirror is broken and think that they are talking to their reflections, which look 'somehow younger'. Such visual and mimic vitality common in cabaret in Germany (see Jelavich I993: 83) were important non-verbal devices employed in Weinstein's show.

The alleged bad business ethics of Jewish merchants and deceitfulness of the clothing trade is the central theme in the one-act comedy Der tsebrokhener shpigl. Whilst $\mathrm{Mr}$ and Mrs Grossist are out, the butler and the maid discuss their life prospects. The butler would like to 'open a door' which the maid, a naïve figure, understands as becoming a thief. What the butler really means is to open a business, a confection shop 'like everyone else'. The comedy had actually started with a scene in which the butler steals some of $\mathrm{Mr}$ Grossist's cigars, citing a Talmudic phrase: Im yogato motsoso! (Seek and you shall find!). ${ }^{13}$ The butler has a 'secret recipe' for success. One has to take:

50 protsent energye, 34 protsent frekbheyt, I5 umerlekhkeyt un misht es tsuzamen mit a $1 / 2 \%$ erlekbkeyt un a $1 / 2 \%$ libe eyner tsum andern.

50 per cent energy, 34 per cent impudence, I5 per cent dishonesty, and to mix it with half per cent honesty and half per cent love of the other.

And the mixture had to be taken every morning, immediately after morning prayers. The maid, shocked by the low percentage of love, throws a shoe at the butler when he tries to hug her but hits the mirror, which shatters. The play has an ironic end as the maid, impressed by the butler's ability to deceive the master and mistress with the mirror reflection trick, and to place the blame of the broken mirror on the master, accepts his recipe for success with 'half a per cent of love of the other'.

In the couplet Yidishe yikhes (Jewish lineage), Mr Chatzkelson commits an insurance fraud by setting fire to his shop to save his business from bankruptcy (sung to the melody of Fishel Singer's Yidl mit zayn fidl):

\section{Far eynike jorn zurik iz geshen \\ Az der sezon iz geharget geven \\ Un di gesheftn teyte, khotsh nem un makh a pleyte \\ Un ikh hob keyn retung nit gezen. \\ Hot zikh mir getrofn a shabes tsu nakht}

13 The Hebrew phrase refers to Rabbi Yitzhak's teachings in the Babylonian Talmud, Megillah 6b. 
A sho nokb der havdole, vi ikh shtey mir un trakbt,

Shrayt tsu mir Khaym Zlates: Es brenen dayne shmates!

Do shpringt mayn vaybl oyf un zingt un lakbt:...

Some years ago it happened

The season was going to hell

And business was dead, near bankruptcy

And I did not see any way out.

It happened to me one Saturday evening

An hour after the Havdalah, ${ }^{14}$ when I was just standing and thinking,

Khaym Zlates shouts out to me: Your rags are on fire!

Then my wife jumps up and laughs: ... of the Jewish community and its religious establishment. Officially, the community was still Orthodox and represented East European Litvak orthodoxy (ibid. II-I2, I8). In the refrain, Mrs Chatzkelson praises her husband's virtues: 'Mayn man reb Khatsklzon ver ken im epes ton?' Azoy geytyedn vemen Got hot nor gebentsht' ('My husband Mr Chatskelson, who can compete with him? / This is the way it goes for everyone who is blessed by God').

This negative, self-deprecatory image of a Jewish merchant "with 15 per cent dishonesty' could be considered as in-group humour, told by one Jew to another, 'harmless' since the actors and audience were all Jews. Jelavich has considered the humorous depiction of Jews in the Berlin cabaret of Schall und Rauch in the 1920 as in-house jokes among actors and
On top of breaching secular law, Mr Chatzkelson also breaks the fourth commandment by keeping his shop open on the Holy Shabbat, something that the Helsinki rabbi fiercely opposed by commanding shopkeepers to lock their doors. Weinstein does not mention the name of the rabbi, but the only official rabbi in post in 1929 was Scholem Treistman (Muir and Tuori 2019: 19-20).

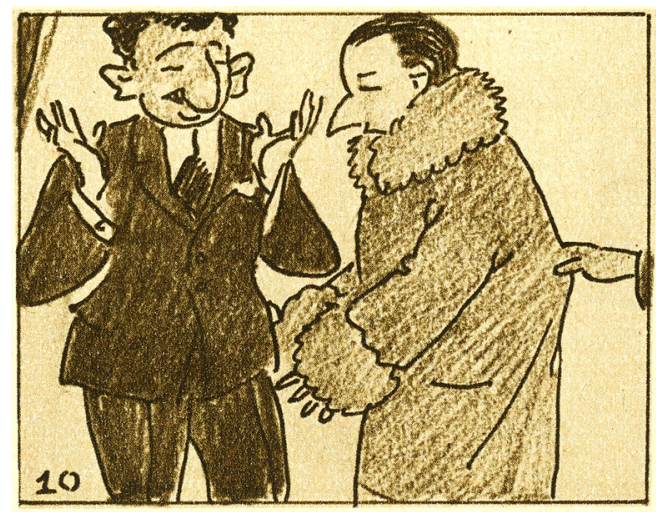

"Htha - oi, she layty olla shellaise bilgd, et shiin - gutistumishe vara..." -. Junnu osti.

Fig. 3. A fragment of an antisemitic cartoon from a mainstream family picture magazine called Suomen kuvalehti in November 1927 in which a Junnu Kivanen is swindled by a Jewish merchant. The merchant's line is a parody of Jewish-Finnish. The text reads: "'The sleeve - it has to be long like that so that it can shrink ..." - And Junnu bought it'. National Library of Finland. an invited audience (Jelavich I993: 79). The negative image of a Jewish business and stereotypes of Jewish merchants in Weinstein's New Year's revue would, however, suggest that these had been issues during the past year, as the revues generally concentrated on the previous year's events. One indicator of the popularity of such stereotypes among the broader society was the appearance in November 1927 As soon as the rabbi disappears, Mr Chatzkelson opens the door again. The song indicates the clash between the growing secularisation among the members

14 Prayer that marks the symbolic end of Shabbat. of a dishonest Jewish clothing merchant in a popular comic strip published in a mainstream family picture magazine called Suomen Kuvalehti (Veli Giovanni 1927; Hanski 2006: II5; Kuparinen 2008: 27I). In the story, the young forthright protagonist Junnu Kivanen 
goes to a Jewish clothing store to buy a winter jacket, only to be swindled by merchants with exaggerated 'Semitic' features (see Fig. 3). By the end of the I920s, Jewish merchants were increasingly attacked in daily newspapers, and even more so in the antisemitic press (Hanski 2006: I24-43). This stigma on Jewish trade was not new, as stereotypical depictions of Jews and Jewish merchants had featured in Finnish newspaper articles and cartoons of humour magazines since the 1880 os (Forsgaird 2002).

\section{Stereotypes of vulgar behaviour}

The sketch $A$ bild fun Henriksgas (Scene from Henrik's Street) in Swedish and Jewish-Swedish satirises the ruthlessness and vulgarity - the ' 34 per cent impudence'- of which Jewish clothing shop keepers were accused, especially in antisemitic caricatures. The scene also depicts the fierce competition among Jews in the branch.In the sketch, two neighbouring clothing retailers try to lure the same passer-by into their shops by dragging him by the sleeves of a coat that the first merchant has managed to force on him. The Swedish-speaking passer-by, the goy, as Weinstein names the character, is a caricature of a 'typical Finn': shy, hesitant, but stubborn:

GOY

Nu ä' de' ju billigt. - Men int'vet ja' om jag köper.

\section{KONFEKTSYONER}

Bilach, scheier ni! Bilach och bilach ä' inte glaich. (Tsit im farn arbl.)

$N u$ kom in lechål-apåches. De' koschtar ingenting att titta!

(Tsit im farn arbl.) (Arayn der 2 konfektsyoner)

\section{KONFEKTSYONER}

(Loyft tsum goy, tsit im baym andern arbl.) Vaschka ni tro honom? Han har bara dåli' vara som håller från Ester tånes bis purim. Mina kuschtjumer har de' finaste tig à' de' finaste tillbeheiver. Harrn schka komma me' mej! (Tsit im.)
GOY

It is cheap indeed. - But I'm not sure if I will buy it.

\section{FIRST CLOTHING MERCHANT}

Cheap, you see! Cheap and cheap are not the same thing.

(Pulls him by the sleeve.)

Come in anyway. It costs nothing to look! (Pulls him by the sleeve.) (In comes the second clothing merchant.)

\section{SECOND CLOTHING MERCHANT}

(Runs to the goy, pulls him by the other sleeve.)

Why should you believe him? He has only lousy merchandise that lasts from the Fast of Esther to Purim [i.e. one day]. My costumes are made of the best materials and the best accessories. The gentleman shall come with me!

(Pulls him.)

Eventually both sleeves of the coat rip, which causes a big uproar. A policeman arrives at the scene to see what all the fuss is about. The sellers blame everything on the passer-by, the goy, and he is taken away by the police. In the end the two 'competitors' go hands on shoulders to a nearby fancy café called Primula at the corner of Henrik Street and Kaleva Street, cursing the goy and calling him an 'antisemite'. By turning things upside down, making the merchants in the story the victims and the non-Jewish passer-by the villain, Weinstein is obviously questioning the dealers' behaviour. The Jewish merchants on Henrik Street, kibitzing in front of their shops and interfering with each other's businesses, are also depicted in a couplet called Khayke Tshort (Khayke the Devil). In it, a fearsome yidene, a Jewess, threatens men with vitriol and violence. Her role is performed by a cross-dressing man to underscore her masculinity and unattractiveness. She tells about her husband, who is trying to do business on Henrik Street, where he speaks with his hands in the 'Jewish parliament' ('Dort redt er mit di 
bent in dem yidishn parlament'). The behaviour of Jewish merchants was discussed in Helsinki newspapers and the police tried to eradicate it, which was said to cause disturbance to the passers-by (see Helsingin Sanomat 1927). Some merchants were even prosecuted for this. Helsingin Sanomat even published antisemitic cartoons by Tiikeri (Arvo Tigerstedt) depicting the Jewish merchants of Helsinki (e.g. Tiikeri 1930). Such was the spread of this offensive image of the Henrik Street Jewish merchants among the town's people that the community took measures to cleanse the public image of the Jews. Nearly a year after Weinstein's revue, in November 1930, a group of Jewish merchants came up with statutes aimed at eradicating what they called 'despicable business methods' (Ekholm 2005: 183; Memorandum 1930). The rules forbade such things as 'lurking' in front of the shops and interfering with neighbouring businesses, and they advised that shop doors be kept closed. Writing about Jewish self-criticism and selfhatred, the historian Todd Endelman (20Ir: II8) has claimed that 'having identified with the societies in which they lived, acculturated Jews saw themselves and other Jews through Christian spectacles, if not at all times then at least some of the time. Inevitably, there were occasions when they experienced the behaviour of other Jews as embarrassing or shameful'. Weinstein's humorous depiction of the merchants on Henrik Street could thus be seen as providing a compensatory pleasure to Helsinki Jews who were - to borrow Wisse's (2013: 35) words - 'under the double weight of their own disciplined heritage and the collective responsibility to behave well among nations'.

\section{Linguistic stereotypes}

Besides satirising merchants' behavior, Weinstein also parodies the way they talk, as apparent in the sketch above. According to Jacobs (2002: 204), 'language play involving performative code switching - i.e., the intentional deconstruction of speech varieties, and the conscious rearrangement or recombination of styles, codes, etc.' was characteristic for emancipated and assimilated Jewish cabaret. When talking to non-Jews, all characters in Weinstein's revue speak an imitation of Jewish-Swedish. An analysis of Weinstein's parody of Jewish-Swedish shows that it contains many distinct linguistic features that are different from the quasi-Jewish-Swedish found in antisemitic caricatures in the Finnish press (Muir 2006: 544-5). A parody of Jewish-Swedish is also used in the couplet Undzer budzhet (Our budget), where members of the Jewish community are lamenting, to the melody of Volga boatmen, the high budget of the Jewish congregation. During the economic depression, some members of the Jewish community, who were also becoming increasingly secularised, and failed to pay their community tax. In the song, the chair of the community explains to the non-Jewish janitor of the synagogue why he cannot be paid on time:

\section{... Herrn, va' scho god}

Sche min kleiderbod, jach har zores oifn pud. Un schäschongen va' schå dåli', Herre God! Ni farshtår nok alein, schnella herrn, Jach mus schälja varor untern kern.

\section{... Sir, be so kind,}

See my clothing booth, I have tons of problems.

An the season has been so bad, oh Lord!

You understand yourself, dear sir,

I have to sell merchandise below the market price.

The excerpt includes sound shifts replacing hissing /s/ with hushing /sh/, the universal marker of Jewish-Swedish, e.g. scho 'so', sche 'see' (cf. Swedish så, se); a lexical item transferred 
from Yiddish, e.g. kleyderbud 'clothing booth' (cf. Swedish kläder stånd); and an idiomatic Yiddish saying, tsores oyfn pud, lit. 'problems that could be measured in poods' (Russian unit of weight, approx. 36 pounds, $161 / 2 \mathrm{~kg}$ ). PseudoYiddish had been typical for Hebrew comedy in American vaudeville, and many cabarets in Germany employed (Jewish) actors who imitated various dialects of East European Jews, besides parodying their customs. Language use in revues had become a means of focusing on larger societal issues of nation, class, ethnicity, gender and so forth (Jacobs 2002: 203). On the one hand, Weinstein (himself with university-level education in Swedish) was parodying the speech of some Helsinki Jews for whom Swedish was a second language and whose language acquisition was incomplete. Yiddish influence on Swedish also stemmed from bilingualism in the community and limited contact with Finns. A school inspection from 1930 of the Jewish Co-educational School in Helsinki, where the official languages of instruction were Swedish and Hebrew, reported that the children were 'semi-lingual', unable to properly speak either Swedish or Yiddish (Muir 2018: 32, 52). On the other hand, Weinstein could be seen as parodying the Yiddish-influenced Swedish attributed to Jewish merchants in caricatures in Swedish and Finnish-language humorous magazines and the press. This was the type of language Jews were expected to speak, and members of the majority could also parody it. Moreover, Yiddish was becoming increasingly stigmatised as an epitome of a mixed and impure language. Adolescents, especially, found it embarrassing to speak Yiddish in public (Muir 2004: II; Muir 2006: 540).

\section{Stereotypes of gender roles and sexual behaviour}

In his New Year's revue, Weinstein does not break away from the stereotypical depiction and social norms concerning Jewish women on stage in the late nineteenth and early twentieth centuries. As with the Jewish merchant, we can see similarities between the representation of Jewish women in Weinstein's revue and that of American vaudeville. Asexual Jewish women characters in Weinstein's revue, i.e. the caring Jewish mother in Lullaby, the fearsome (old) Jewess in Khayke Tshort, the nagging wife and fiancée in Der tsebrokhener shpigl, contrast sharply with non-Jewish women. According to Erdman, the female Jewish body seemed nearly incompatible with vaudeville (Erdman I997: 156, 158). This was also evident in Russian variety performances; for instance, the Russian actor Pavel Veinberg, who visited the Alexander Theatre in Helsinki at the beginning of the twentieth century, performed the role of a Jewess in drag in his Hebrew comedy (Byckling 2009). In Weinstein's revue, however, there are numerous insinuations of flirtation and extra-marital relations between Jewish men and non-Jewish women. According to Jelavich (1993: 96), oblique songs and scenes of extra-marital relations and sex in general were at the core of cabaret. Both Mr Grossist in Der tsebrokhener shpigl and $\mathrm{Mr}$ Chatskelson of Yidishe yikhes had been dancing and flirting with women 'oyf Fennias pol, on the dance floor of Fennia, which was one of Helsinki's finest nightclubs in the 'roaring twenties'. In Der tsebrokhener shpigl, Mr Grossist sings, after returning home, the refrain of a popular song from 1928 by the Swedish revue king Ernst Rolf, starting with the allusive sentence: 'Jag är ute när gumman min är inne, jag är inne när gumman min är ut' ('I am out when my missus is in, I am in when my missus is out').

The theme of the one-act comedy Di kukle oder der gebrokhener neyder (The doll or the broken oath) is the flirting that takes place in a clothing store, again a stereotype found in the antisemitic press of the time (see Kuparinen 


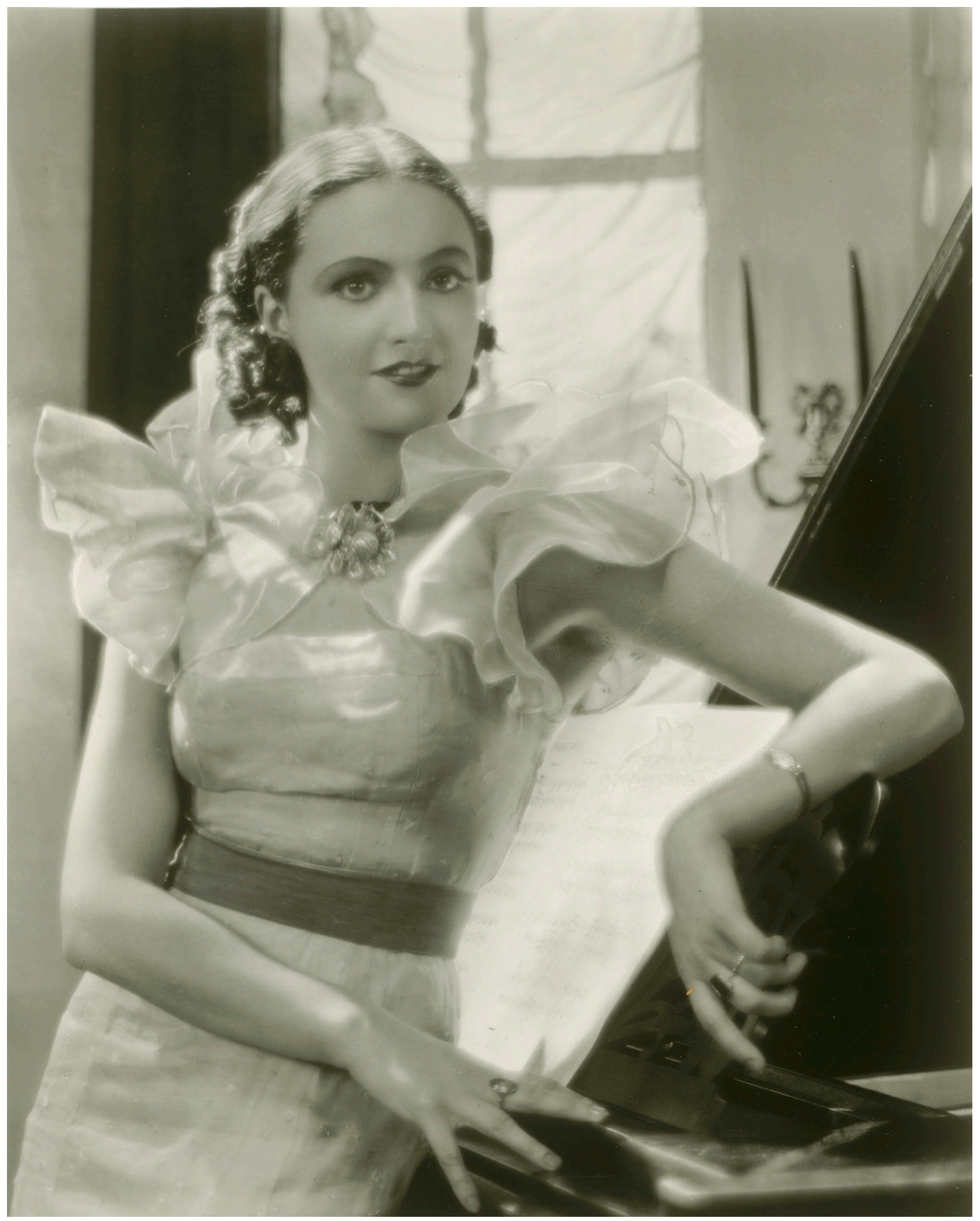

Fig. 4. Hanna Schlimowitsch (1911-96) played the role of a Parisian mannequin in the sketch Di kukle oder der gebrokhener neyder (The doll or the broken oath). Schlimowitch, who acted in the Jewish Dramatic Society from an early age, became a very popular Finnish film star under the stage name Hanna Taini. The picture is from her role in the film Siltalan Pehtoori (of Steward of Siltala), 1934. Finnish Jewish Archives, National Archives of Finland. 
2008: 272). ${ }^{15}$ In the sketch, Mr Kleiderman (lit. 'clothier') receives a mannequin from Paris and he is attracted by its beauty, clad in a stylish short dress without sleeves. The doll was played by Hanna Schlimowitsch, known for her striking beauty (see Fig. 4). The story is a humorous twist on a Hassidic tale in which a pious Jew vows to donate money for a holy cause in order to cross a bridge safely. In $D i$ kukle, Mr Kleiderman jokingly vows to donate a large sum of money to a yeshiva in Jerusalem should the mannequin come to life. Suddenly, the mannequin starts to move and speaks in French. Mr Kleiderman flirts with her, peeps under her skirt and sings and dances Parisian cabaret melodies with her. He orders food and wine, and a bed from the biggest department store in town, Stockmann's. When Mrs Kleiderman appears, Mr Kleiderman, exhausted, tries desperately to wipe the lipstick off his face. In the Hasidic story, the pious Jew cancels the oath after crossing the bridge safely, but, crossing back for something he has forgotten on the other side, he falls into the river. In the revue, $\mathrm{Mr}$ Kleiderman refuses to give a donation to a messenger, who happens to come by to collect money for the institution in Jerusalem, and the mannequin becomes lifeless again. The fact that $\mathrm{Mr}$ Kleiderman flirted with a 'doll' and not a 'real girl' gave this quasi-sexual encounter a sense of estrangement that made it socially more acceptable. In addition, the sexist representation of a young female is that of a gentile Parizer kukle, a Parisian dolly, not a yidishe tokhter, a Jewish daughter. Similar scenes of lecherous Jewish men lusting after randy nonJewish girls had been popular in American

15 Weinstein reworked the sketch in 1940 into a one-act musical comedy called $A$ komedye vegn undz yidelekh (A comedy of us Jews), which was performed at the Balder Theatre in Helsinki, most likely as part of a New Year's revue (Muir, forthcoming). vaudeville from the late nineteenth century as well as in the German cabaret of the early twentieth century (Erdman 1997: Ir8; Jelavich I993: 96).

\section{Contesting the stereotype of a 'ghetto Jew'}

The final stereotype in Weinstein's revue is connected with the physicality of Jews, especially Jewish men. Weinstein's merchant is a positive anti-hero who proves his business savvy. A similar type can be found in many anecdotes about Jewish merchants, told even today among Jews in Finland, and how they always manage to succeed using one trick or another (Muir 2006: 547-8). However, in physical skills the triumph was not always guaranteed. The couplet $A$ shtern fun bolplan (A star from the football field) tells about the defeat the football team of the Jewish sports club Stjärnan (Swedish, The Star) suffered in a match against a non-Jewish Finnish team. The melody of the couplet was adopted from the melancholic Yiddish operetta song Fun Shpanye (From Spain) by Zvi Hirsch Gershoni, which was in the repertoire of the Jewish Song Association in Helsinki. Gershoni's song is about the hardships of the Jewish people in the Diaspora, which adds a layer of irony to Weinstein's couplet:

\section{Oyfn plan bin ikh haynt gevezn a held. Kh'hob geshlaydert dem bol vayt ibern feld. Iz gekumen fun bintn a gazlen, a goy Un hot a brike geton in mayn - oy, oy, oy, oy!}

On the field I was a hero today I flung the ball far over the field. From behind came a villain, a goy And gave a kick in my - oy, oy, oy, oy!

The sports association made it possible to experience and to depict a healthy and masculine image of a Jew, compared to the stereotypical ghetto or bourgeois Jew, seen as weak, effeminate 
and cowardly (Stanislawsky 20or: 91; Ekholm and Muir 2016: I80-I). Sport was also a way to encounter non-Jews, and was vital to integration in Finnish society. The ambitions were high - The Star's football team tried hard to join the Finnish champions'league, and finally managed to do so in I93I (Weintraub 2006:74).

\section{Conclusions}

As the analysis has shown, practically all of the Jewish stereotypes in Jac Weinstein's New Year's revue from I929 are widespread transnational tropes of popular entertainment from the late nineteenth century and the first decades of the twentieth century. These ethnic stereotypes, performed by Jews and non-Jews alike, can be found in American vaudeville, Russian variety theatre, Weimar Republic cabaret and in shows put on in Helsinki. At the core of these stereotypes was the image of a deceitful Jewish merchant, which also features prominently in Weinstein's New Year's revue. Besides deceitfulness, the stereotypes found in the revue include vulgarity, poor acquisition of local languages and allusions to sexual behaviour between Jewish men and non-Jewish women. It is only with the rise of political antisemitism in the I920s that concern over the harmful effects of the Jewish stereotypes grew and they became unpopular, for instance in the Weimar cabaret. It is at this turning point that we still find these stereotypes in Weinstein's revue.

In many ways, Weinstein's New Year's revue was a testing ground for evaluating the achievements, failures and limitations of Jewish integration into Finnish society. The revue celebrates the success of the Jewish merchants in the retailing of ready-to-wear clothing. At the same time, it satirises the downside of the concentration within a single branch of activity, especially at a time of economic depression. The revue expresses the growing concern of the young about their future and the clash between increasing secularisation and the religious Jewish establishment, amplifying the internal tension within the Jewish community.

Performing the Jewish stereotypes in this setting to an insider group in Yiddish could be considered safe. I would argue, though, that the Jewish stereotypes in Weinstein's revue go beyond mere repetition of similar motifs in transnational entertainment and reflect the increasing pressure of antisemitism in Finnish society. Research into Finnish everyday antisemitism, especially in the press, corroborates this argument. Also, documents from the Jewish community, such as the memorandum of Jewish merchants in 1930, show how this community tried to fight back with practical measures. Performing the Jewish stereotypes in Weinstein's revue gave Finnish Jews a chance to deal with the occasional tensions within the community and with the growing pressure from outside, and to gain a measure of relief through biting satire and humour.

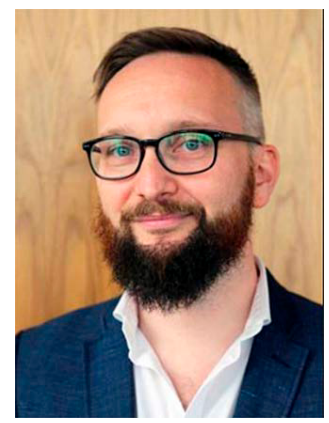

Dr Simo Muir is currently an honorary research associate at the Department of Hebrew and Jewish Studies, University College London, and he is the $\mathrm{Pl}$ of the Kone Foundationfunded project 'Diasporas of the Music Industry and their Finnish Connections'. He received his $\mathrm{PhD}$ in Yiddish linguistics at the University of Helsinki in 2004, and has published widely on Jewish history in Finland. His latest articles include "'Mother Rachel and her children": artistic expressions in Yiddish and early commemoration of the Holocaust in Finland' (East European Jewish Studies, 48(3), 2018) and, co-authored with Dr Riikka Tuori, "'The Golden Chain of Pious Rabbis": The origin and development of Finnish Jewish Orthodoxy' (Scandinavian Jewish Studies, 30(1), 2019). 


\section{Bibliography}

Berkowitz, Joel (ed.), 2003. Yiddish Theatre: New Approaches (Oxford, Littman Library of Jewish Civilization).

— and Barbara Henry (eds.), 20I2. Inventing the Modern Yiddish Stage: Essays in Drama, Performance and Show Business (Detroit, Wayne State University Press).

Bułat, Mirosława M., 20Io. 'Kleynkunst', in YIVO Encyclopedia ofJews in Eastern Europe <https:// yivoencyclopedia.org/article.aspx/ Kleynkunst>

Byckling, Lisa, 2009. Keisarinajan kulisseissa: Helsingin Venäläisen teatterin historia I868-I9I8 (Helsinki, SKS).

Caplan, Debra, 2018. Yiddish Empire: The Vilna Troupe, Jewish Theater and the Art of Itinerancy (Ann Arbor, The University of Michigan Press).

Ekholm, Laura, 2005. 'Heikinkadun juutalaiset vaatekauppiaat: Juutalaiset tekstiilialan yrittäjät Igoo-luvun alun Helsingissä, in Vieraat kulkijat, tutut talot: näkökulmia etnisyyden historiaan, ed. Antti Häkkinen, Panu Pulma and Miika Tervonen (Helsinki, SKS), pp. 167-94.

- 2006. 'Making a living', in Lechaim! Images of the History of Jerws in Finland, ed. Dan Kantor et al. (Helsinki, The Jewish Community of Helsinki), pp. IO2-I9.

-2013. Boundaries of an Urban Minority: The Helsinki Jewish Community from the End of Imperial Russia until the r97os. Publications of the Department of Political and Economic Studies II, $\mathrm{PhD}$ dissertation, University of Helsinki <https://helda.helsinki.fi/ handle/10138/41009>

2019. 'Jews, second-hand trade and upward economic mobility: introducing the readyto-wear business in industrializing Helsinki, I880-1930', Business History, 6I(I), pp.73-92, doi: <https://doi.org/10.1080/00076791.201 8.1546694>

- and Simo Muir, 2016. "Name changes and visions of "a new Jew" in the Helsinki Jewish Community', in Jewish Studies in the Nordic Countries Today. Scripta Instituti Donneriani Aboensis 27, ed. Ruth Illman and Björn Dahla (Åbo,Donner Institut),pp. I73-88, doi: <https:// doi.org/10.30674/scripta.66574>

Endelman, Todd M., 20II. Broadening Jerwish History: Towards a Social History of Ordinary Jerws (London, The Littman Library of Jewish Civilization).
Erdman, Harley, 1997. Staging the Jew: The Performance of an American Ethnicity, I860-I920 (New Brunswick, Rutgers University Press).

Forsgård, Nils-Erik, 2002. Alias Finkelstein: Studier $i$ antisemitisk retorik (Esbo, Schildts).

Hanski, Jari, 2006. Juutalaisvastaisuus suomalaisissa aikakauslehdissä ja kirjallisuudessa I9I8-1944, $\mathrm{PhD}$ dissertation, University of Helsinki <https://helda.helsinki.fi/bitstream/ handle/10138/21807/juutalai. pdf?sequence $=2>$

Helsingin Sanomat, I927. 'Heikinkadun juutalaiskauppiaiden kadulla seisoskeleminen', Helsingin Sanomat, I2 May I927.

Jacobs, Neil, 2002. 'Soirée bei Kohn: Jewish elements in the repertoire of Hermann Leopoldi', in Zutot 2002, ed. Shlomo Berger, Michael Brocke and Irene Zwieb (Dordrecht, Kluwer Academic Publishers), pp. 200-8.

Jelavich, Peter, 1993. Berlin Cabaret: Studies in Cultural History (Cambridge, MA, Harvard University Press).

Kuparinen, Eero, 2008. Antisemitismin musta kirja: juutalaisvainojen pitkä historia (Jyväskylä, Atena).

Lachs, Vivi, 20I8. Whitechapel Noise:Jewish Immigrant Life in Yiddish Song and Verse, London I884-I9I4 (Detroit, MI, Wayne State University Press).

Memorandum 1930. 'Samlade till möte ...', II November 1930, National Archives of Finland, Finnish Jewish Archives, box I67.

Muir, Simo, 2004. Yiddish in Helsinki: Study of a Colonial Yiddish Dialect and Culture (Helsinki, Finnish Oriental Society).

— 2006. 'Jiddišistä ruotsin kautta suomeen. Helsingin juutalaisten kielenvaihdoista ja etnolektistä', Virittäjä, II3(4), pp. 533-56.

-2010. 'Jac Weinstein (1883-1976)', in Kansallisbiografia-verkkojulkaisu, Studia Bibliographica 4 (Helsinki, SKS) <https://kansallisbiografia.fi/ kansallisbiografia/henkilo/9302>

- 2013. 'Modes of displacement: ignoring, understating and denying antisemitism in Finnish historiography', in Finland's Holocaust: Silences of History, ed. Simo Muir and Hana Worthen (Basingstoke, Palgrave Macmillan), pp. $46-68$.

— 2018. 'Juutalaisaineiden opetus', in Kyläkoulu keskellä kaupunkia - Helsingin juutalainen yhteiskoulu roo vuotta, ed. Dan Kantor et al. (Helsinki, Helsingin Juutalainen Yhteiskoulu), pp. $45-57$. 
— forthcoming. "Between the "free zone" and the "Jew zone": Jewish performing arts in Axisallied Finland'.

— and Riikka Tuori, 2019. "The Golden Chain of Pious Rabbis": The origin and development of Finnish Jewish Orthodoxy', Scandinavian Jewish Studies, 30(I), pp. 8-34, doi: <https:// doi.org/10.30752/nj.77253>

Nahson, Edna, 20I6. 'Entertaining the crowd', in New York's Yiddish Theater. From the Bowery to Broadway, ed. Edna Nahson (New York, Columbia University Press), pp. 240-7.

Nudelman, M., I968. 'Kleynkunst- un maryonetnteaters', in Yidisher teater in Eyrope tsvishn beyde velt-milkhomes. Poyln, eds. Itsik Manger et al. (New York, Alveltlekher yidisher kulturkongres), pp. I48-68.

Pollak, Oliver B., and Leo Greenbaum, 1998. 'The Yiddish Theater in Omaha, I919-1969', in Yiddish Language and Culture: Then and Now, ed. Leonard Jay Greenspoon (Omaha, Creighton University Press), pp. I27-63.

Program, I929. 'Program vid Judiska Dramatiska Sällskapets revyafton', 3I December I929. National Archives of Finland, Finnish Jewish Archives, box 460.

Rapaport, Lynn, 2005. 'Laughter and heartache: the function of humor and Holocaust tragedy', in Grey Zones: Ambiguity and Compromise in the Holocaust and its Aftermath, ed. Jonathan Petropoulos and John K. Roth (Oxford, Berghahn Books), pp. 252-69.

Sandrow, Nahma, I977. "A little letter to Mamma”: Traditions in Yiddish vaudeville', in American Popular Entertainment, ed. Myron Matlaw (Westport, Greenwood Press), pp. 87-95.
— 1996. Vagabond Stars: A World History of Yiddish Theater (Syracuse, Syracuse University Press).

Seppälä, Mikko-Olavi, 2009. Hauska poika: kuplettilaulaja J. Alfred Tanner (Helsinki, WSOY).

Shternshis, Anna, 2006. Soviet and Kosher: Jewish Popular Culture in the Soviet Union, 1923-1939 (Bloomington, Indiana University Press).

Stanislawsky, Michael, 20or. Zionism and the Fin de Siècle: Cosmopolitanism and Nationalism from Nordau to Jabotinsky (Berkeley, University of California Press).

Steinlauf, Michael C., 2010. 'Theater: Yiddish Theater', in YIVO Encyclopedia of Jews in Eastern Europe <https://yivoencyclopedia.org/ article.aspx/Theater/Yiddish_Theater>

Thissen, Judith, 2016. 'Early Yiddish vaudeville in New York City', in New York's Yiddish Theater. From the Bowery to Broadway, ed. Edna Nahson (New York, Columbia University Press), pp. 248-54.

Tiikeri [Arvo Tigerstedt], I930. 'Akateemikot juoksivat ..., Helsingin Sanomat, 4 May 1930.

Veli Giovanni [H.J. Viherjuuri], I927. 'Junnu ostaa talvitakin', Suomen Kuvalehti (lisä-ajanvietesivu no. 45), I2 November 1927.

Weinstein, Jac, [1929]. 'Revyafton', unpublished manuscript, National Archives of Finland, Finnish Jewish Archives, box 460.

Weintraub, Daniel, 2006. 'The social life in the community', in Lechaim! Images of the History of Jews in Finland, ed. Dan Kantor et al. (Helsinki, The Jewish Community of Helsinki), pp. 54-77.

Wisse, Ruth R., 20I3. No Joke: Making Jerwish Humor (Princeton: Princeton University Press). 